\title{
Assessment of mangrove species diversity in Banaybanay, Davao Oriental, Philippines
}

\author{
BRIAN L. POTOTAN", NEIL C. CAPIN ${ }^{\natural », ~ A I L E E N ~ G R A C E ~ D . ~ D E L I M A ~}{ }^{\vee \vartheta}$, ANNABELLE U. NOVERO ${ }^{\natural \vee \vartheta}$ \\ Department of Biological Sciences and Environmental Studies, College of Science and Mathematics, University of the Philippines Mindanao, Mintal, \\ Tugbok District, Davao City 8022 Philippines. Tel./fax.: +63-2930302, ‘email: bruguieraspp@gmail.com; ‘"neilcapin07@gmail.com; \\ vvvaddelima @up.edu.ph; vwvaunovero@up.edu.ph
}

Manuscript received: 5 November 2020. Revision accepted: 15 December 2020.

\begin{abstract}
Pototan BL, Capin NC, Delima AG, Novero AU. 2021. Assessment of mangrove species diversity in Banaybanay, Davao Oriental, Philippines. Biodiversitas 22: 144-153. This study determined mangrove species diversity and community structure in Banaybanay, Davao Oriental, Philippines. Ten $150 \mathrm{~m}$ long transects plots were laid out perpendicular through the mangrove forests yielding 30 plots and total sampled area of $3,000 \mathrm{~m}^{2}$. Individual trees within plots were counted, identified and measured for diameter at breast height (dbh) and tree height. For diversity analysis, Shannon-Weiner Index of Diversity (H'), Pielou's Index of Evenness (J), Simpson's Index of Dominance (C), and Effective Number of Species (ENS) were used. Results showed a total of 33 species belonging to 14 families, 31 of which are true mangroves and two associates. Two threatened species, the endangered Camptostemon philippinensis and vulnerable Avicennia rumphiana, and three near-threatened species were recorded. Diversity analysis showed a high diversity index $\left(H^{\prime}=3.145\right.$; ENS=23) and high species evenness $(J=0.85)$ but low dominance $(C=0.05)$. Sonneratia alba attained the greatest importance value (IV=59.79\%) due to high relative density, relative frequency, and relative dominance. Also, Rhizophoraceae is the most represented among 14 families. Hence, Banaybanay being highly diverse with the presence of threatened and near-threatened mangrove species calls for immediate protection and conservation measures because of increasing anthropogenic activities and environmental problems observed in the area.
\end{abstract}

Keywords: Camptostemon phillippinensis, Davao Gulf, diversity, importance value, mangrove, Sonneratia alba

\section{INTRODUCTION}

Mangroves are species of plants that thrive in intertidal areas that vary from trees, vines, ferns to palms (Tomlinson, 1986). Many of the mangrove experts classify these plants into true and associate species. True mangroves, are those species that can only thrive in mangrove habitat while the associate species can exist both on the aquatic and terrestrial, and can also be found in mangrove areas (Food Agriculture Organization 2010; Dieta and Dieta 2015). These mangroves provide tremendous ecological and socio-economic benefits (Bandaranayake 1998; Primavera et al. 2004).

During typhoons, mangrove ecosystem acts as a natural barrier and reduces the risk of coastal flooding and soil erosion (Bagarinao and Primavera 2005). It serves as a nursery to different species of marine life by providing them food and protection against predators. To coastal communities, mangroves are valuable resources for building materials, fodder for livestock, herbal medicine, and source of livelihood (Farley et al. 2010).

Mangrove ecosystem in the Philippines, one of the mega-diverse countries in the world, constantly faces threats due to human activities and other environmental problems (Van Lavieren et al. 2012). At least fifty percent of the world's known species of mangroves are found in the country (Garcia et al. 2014) including threatened species listed as Endangered and Vulnerable (Spalding et al. 1997; Primavera et al. 2014). As estimated by the
Department of Environment and Natural Resources (DENR) in 2003, the country had 7.3 million ha. remaining forest, 3\% of which is mangrove (Long and Giri 2011; Bunting et al. 2018; Faustino et al. 2020). In the past decades, mangrove areas in the country continue to decline up to 50\% of their original forest cover (Buitre et al. 2019). The decline of mangrove cover is due to the destruction of mangrove habitat for fishponds, cutting of mangrove trees for charcoal, and source of building materials (Primavera 1995). Assessment of mangrove species plays a vital role in ecosystem protection and conservation particularly in Davao Gulf. Davao Gulf is one of the country's marine key biodiversity area (Conservation International Philippines et al. 2009) surrounded by five provinces of Davao region which are Davao Oriental, Davao de Oro, Davao del Norte, Davao del Sur, and Davao Occidental The gulf is a rich resource for fisheries activities, serves as international port (Alcala et al. 2008), and supports other economic activities. Davao Oriental's coastline is the longest in the country comprising about 3\% (Cabrera and Lee 2018). Among the municipalities situated in the southwestern part of Davao Oriental facing Davao Gulf, Banaybanay ranked first in mangrove forest cover with a total of 137 hectares through the use of light detection and ranging (LiDAR) technology (Novero et al. 2019). However, there is limited information on mangrove species thriving in Banaybanay, hence, it is imperative to assess the diversity of its mangrove forest. In particular, this study aims to determine the species composition, diversity, and community structural features 
of the mangrove forest in Banaybanay, Davao Oriental in the Philippines.

\section{MATERIALS AND METHODS}

\section{Study site}

The survey was conducted last October 2019 in the municipality of Banaybanay, Davao Oriental. Banaybanay is a second-class municipality of Davao Oriental, located at $7.1608^{\circ} \mathrm{N}$ and $126.1601^{\circ} \mathrm{E}$ of Davao Region. As part of Region XI, the municipality is categorized with Type II and Type IV climate, characterized as having no dry season with very pronounced maximum rainfall from November to January and more or less evenly distributed rainfall throughout the year (Philippine Institute for Development Studies 2005). The municipality has six coastal barangays with mangrove forest features (Forest Management Bureau 2010) that include fringing type in Maputi, riverine type in Kalubihan, Mogbongcogon and Piso, and overwash type in Pintatagan and Puntalinao.

\section{Sampling techniques}

Mangrove assessment standard protocol was adapted from English et al. (1994) with modifications following Cañizares and Seronay (2016). A total of ten $150 \mathrm{~m}$ long transect lines were established through the mangrove forests perpendicular to shore (Figure 1). Lengths of transects for mangrove surveys depend on the extent of vegetation cover. Some studies implemented shorter transects such as Picardal et al. (2011) with $100 \mathrm{~m}$,
Calicdan et al. (2015) with $110 \mathrm{~m}$, and Dangan-Galon et al. (2016) from 50 to $100 \mathrm{~m}$. This study is limited to rapid diversity assessment and does not include the zonation patterns of the mangrove forests. The locations of transects and sampling plots were marked using Global Positioning System (GPS).

The number of transects per barangay varies on the extent of the vegetation, with three transects for Maputi, two transects each for Kalubihan and Piso and only one transect each for Mogbongcogon, Pintatagan and Puntalinao. The minimum distance between transects was $500 \mathrm{~m}$ determined using Google Map. Along each transect line, three $10 \mathrm{~m} \times 10 \mathrm{~m}$ quadrats were laid out in $40 \mathrm{~m}$ intervals yielding a total of 30 plots. Within the sampled quadrat, every mature tree with diameter of $10 \mathrm{~cm}$ and above was listed (Nugroho et al. 2019). The diameter at breast height (DBH) of individual trees was recorded using a tree caliper (Haglof Mantax). Tree height was measured using a range finder (TruPulse 200). The stem diameter and height of fern species and Nypa palm were also gathered. However, saplings and seedlings were not included in this rapid mangrove assessment.

\section{Identification of species}

The species found in each plot was identified and classified taxonomically using Primavera et al. (2004), Giesen et al. (2006), Primavera and Sadaba (2012), and Pelser et al. (2011 onwards). The classification of mangroves as true or associate species was based on Giesen et al. (2007) and Primavera (2009).
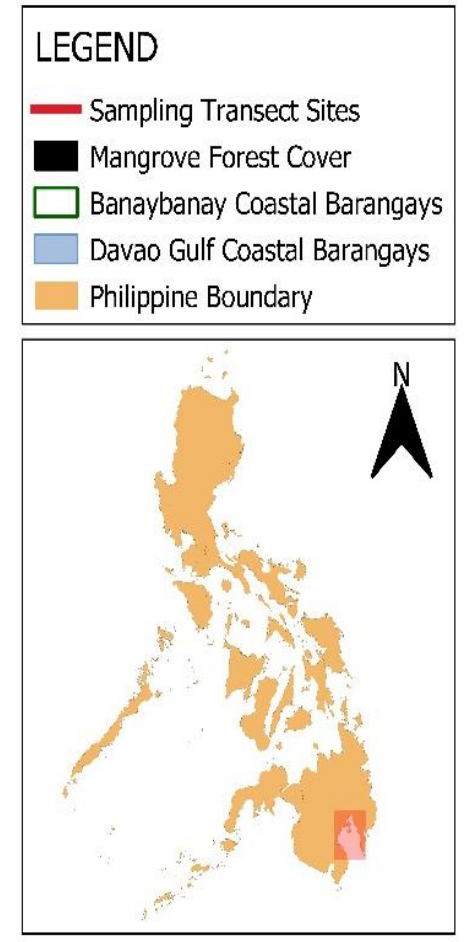

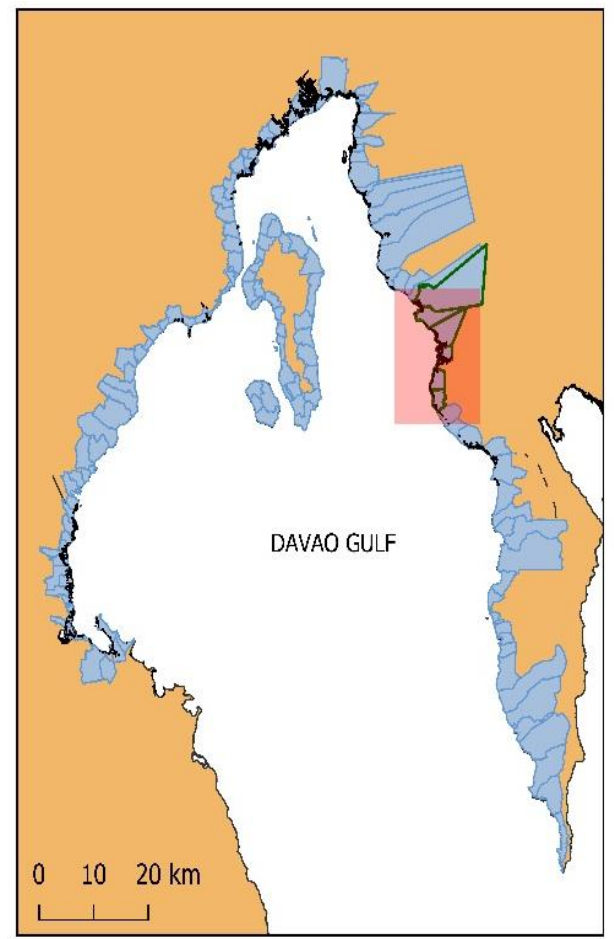

$\begin{array}{llll}0 & 1 & 2 & 3 \mathrm{~km}\end{array}$

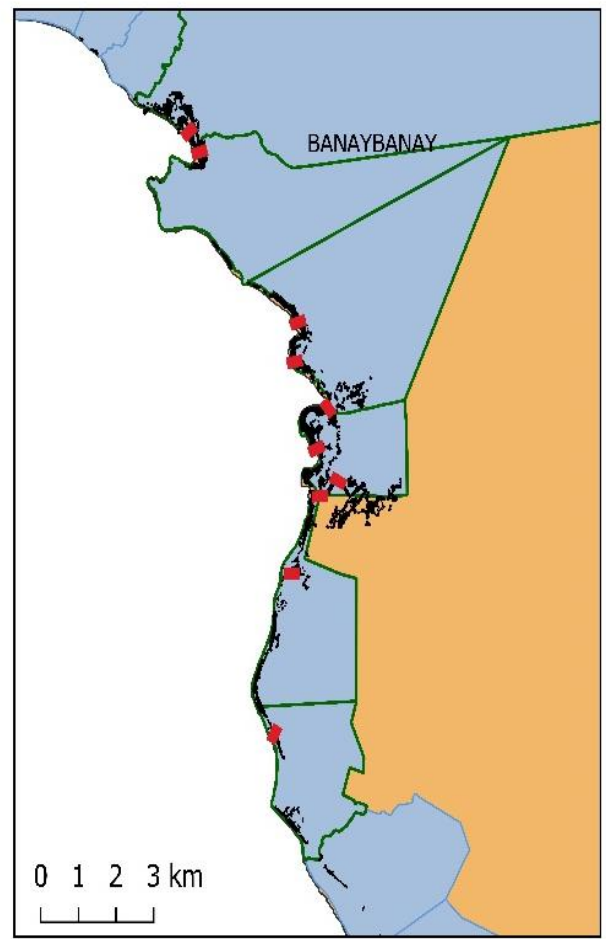

Figure 1. Location of sampling sites in Banaybanay, Davao Oriental, Philippines 


\section{Conservation status}

Conservation status of each species was based on The IUCN Red List of Threatened Species 2010-2, 2011-1 and 2019-3 (https://www.iucnredlist.org/) and Department of Environment and Natural Resources Administrative Order No. 2007-1 (DAO 2007-1) and 2017-11 (DAO 2017-11).

\section{Diversity analysis}

Species richness, diversity, evenness dominance using the indices (Baleta and Casalamitao 2016; Baliton et al. 2020) below were obtained. For interpreting $H^{\prime}$ index, Fernando (1998) classification scheme was used as cited in Baliton et al. 2020. Further, the effective number of species (Cardillo and Novero 2018) for the computed H' index was determined.

Shannon - Weiner Index of Diversity $(H)=-\sum_{i=1}^{s}\left(p_{i} \ln p_{i}\right)$

Where:

H': Shannon-Weiner Diversity Index

$p_{\mathrm{i}}$ : fraction of the entire population made up of species $i$ S:number of species encountered / species richness

$\sum=$ sum from species 1 to species $\mathrm{S}$

Pielou's Index of Evenness $(J)=\frac{H^{\prime}}{\operatorname{lns}(\text { or H } \max )}$

Where:

H': Shannon's Diversity Index

$\operatorname{lnS}$ : natural logarithm of species richness

Simpson's Index of Dominance $(C)=\sum_{i=1}^{s}\left(p_{i}{ }^{2}\right)$

Where:

S:number of species encountered / species richness

$p_{\mathrm{i}}$ : fraction of the entire population made up of species $i$ $\sum=$ sum from species 1 to species $S$

Simpson's Index of Diversity $(D)=1-C$

Where:

C: Simpson's Index of Dominance

Effective Number of Species $=\exp \left(H^{\prime}\right.$ index $)$

\section{Community structure}

For community structural features of the mangrove forest, the following formula was computed based on English et al. (1994). Basal area of individual trees, stand basal area, and stems per ha for each species were calculated. The values for basal area were used in computing for relative dominance. These are the essential factors in identifying the relevance and functions of the different species found in the area.

$$
\begin{aligned}
& \text { Basal area }(\text { per tree })=\frac{\pi \mathrm{DBH}^{2}}{4} \\
& \text { Stand basal area }=\frac{\text { sum basal area per species }}{\text { total area of the plot }} \\
& \text { Stems per ha }=\frac{\text { no.of stems in all plots per species } x 10,000}{\text { total area of the plot }} \\
& \text { Relative density }=\frac{\text { no.of individuals of a species }}{\text { total of no.individuals }(\text { all species })} \times 100
\end{aligned}
$$

$$
\begin{aligned}
& \text { Relative frequency }=\frac{\text { frequency of a species }}{\sum \text { frequency of all species }} \times 100 \\
& \text { Relative dominance }=\frac{\text { total basal area of species }}{\text { basal area of all species }} \times 100 \\
& \text { Importance value }=\sum \begin{array}{c}
\text { Relative density }+ \text { Relative frequency }+ \\
\text { Relative dominance }
\end{array}
\end{aligned}
$$

\section{RESULTS AND DISCUSSION}

\section{Mangrove species composition}

A total of 650 individuals representing 33 plant species belonging to 14 families were recorded in Banaybanay (Table 1). Out of the total species composition, 94\% $(n=31)$ of which are classified as true mangroves while the remaining $6 \%(n=2)$ were mangrove associates. Most of the species found are trees with 28 species $(85 \%)$, shrubs $(6 \%)$ from Acanthaceae, and ferns $(6 \%)$ from Pteridaceae, and lastly one palm species (3\%) from Arecaceae.

For the conservation status of these species, $36 \%$ of total species have threatened status with Avicennia rumphiana as one vulnerable species and one Camptostemon philippinensis as the only endangered recorded. Three (3) species of mangroves were identified as near threatened and these are Aegiceras floridum, Sonneratia ovata, and Ceriops decandra. Moreover, 94\% of mangrove species are at lower risk. According to Garcia et al. (2014), no mangrove species was listed in the National Red List crafted by the Philippine Plant Conservation Committee that was issued as a DENR Administrative Order (DAO) 2007-01. Meanwhile, DAO 2017-11 cited two mangrove species, C. philippinense as endangered and Carallia brachiata (Lour.) Merr. locally known as bakauan-gubat under Rhizhophoraceae as Other Threatened Species. The IUCN Red List of Species version 2010-2 was the reference for most species listed in this study (Duke et al. 2010; Ellison et al. 2010) except for Acanthus ilicifolius using IUCN 2011-1 (Bignoli 2011) and IUCN 2019-3 for Terminalia catappa (Thomson and Evans 2019). Updating of assessments are annotated in the IUCN Red List of Threatened Species, meanwhile, no mangrove species were listed in the latest IUCN Red List 2020-2.

One notable species found is the indigenous and the endangered $C$. philippinensis, locally known as "gapasgapas" (Figure 2). This species is distributed to Luzon, Palawan, Masbate, Panay, Negros, Bohol, Mindanao and Basilan. It can also be found in Borneo and Celebes (Fernando and Pancho, 1980). Using the IUCN 2010-2, there are only 1,200 mature individuals remaining in the wild in the country. The population of this mangrove species is generally decreasing due to anthropogenic threats mainly due to mangrove forest conversion for aquaculture and cutting (IUCN 2010-2) for wood and charcoal. Locally, there are no published reports on the occurrence of this species in Davao Gulf. According to Primavera JH 2020, pers.com. this could be its first sighting in Davao Gulf. In this study, only four mature individual trees were recorded. On the other hand, Avicennia rumphiana which is vulnerable has only 42 individuals in the sampling sites. 
There are also less than 20 individuals for the nearthreatened species.

\section{Mangrove diversity analysis}

The sampled mangrove forests in Banaybanay showed a high species richness of 33 species. In comparison with published surveys on mangroves in neighboring local units around Davao Gulf, Banaybanay is more diverse than Sta. Cruz, Davao del Sur with 17 species (Cardillo and Novero 2018), and Davao del Norte with 11 to 16 different species were obtained in four sites (Pototan et al. 2017).

Using the indices (Table 2), results showed that the sampled mangrove forest showed a high Shannon-Weiner
Index of Diversity $\left(\mathrm{H}^{\prime}=3.145\right)$. To achieve such $\mathrm{H}^{\prime}$ index, the effective number of species (ENS) is 23 species and it has a small difference from the maximum diversity $\left(\mathrm{H}_{\max }=\right.$ 3.496). This also takes into account the high number of species and large number of individuals recorded. Results also showed high species evenness of $89 \%(\mathrm{~J}=0.89)$. With higher species richness and species evenness, the diversity is expected to be higher as well. This in turn resulted in low dominance, $\mathrm{C}=0.05$ of mangrove forest of the municipality which the value is less than 1 . It also shows that the forest is not dominated by single species.

Table 1. Mangrove species identified in Banaybanay, Davao Oriental, Philippines with their conservation status and category

\begin{tabular}{|c|c|c|c|c|}
\hline Species & Family & $\begin{array}{c}\text { No. of } \\
\text { individuals }\end{array}$ & $\begin{array}{c}\text { Conservation } \\
\text { status }\end{array}$ & Life form \\
\hline \multicolumn{5}{|l|}{ True mangroves } \\
\hline Acanthus ebracteatus Vahl. & Acanthaceae & 17 & $\mathrm{LC}^{1}$ & Shrub \\
\hline Acanthus ilicifolius L. & & 5 & $\mathrm{LC}^{2}$ & Shrub \\
\hline Nypa fruticans Wurmb. & Arecaceae & 31 & $\mathrm{LC}^{1}$ & Palm \\
\hline Avicennia alba Blume & Avicenniaceae & 4 & $\mathrm{LC}^{1}$ & Tree \\
\hline Avicennia marina (Forssk.) Vierh & & 45 & $\mathrm{LC}^{1}$ & Tree \\
\hline Avicennia officinalis L. & & 6 & $\mathrm{LC}^{1}$ & Tree \\
\hline Avicennia rumphiana Hall. f. & & 42 & $\mathrm{VU}^{1}$ & Tree \\
\hline Lumnitzera littorea (Jack) Voigt. & Combretaceae & 26 & $\mathrm{LC}^{1}$ & Tree \\
\hline Lumnitzera racemosa Willd. & & 35 & $\mathrm{LC}^{1}$ & Tree \\
\hline Excoecaria agallocha $\mathrm{L}$. & Euphorbiaceae & 6 & $\mathrm{LC}^{1}$ & Tree \\
\hline Sonneratia alba J.E. Smith & Lythraceae & 88 & $\mathrm{LC}^{1}$ & Tree \\
\hline Sonneratia caseolaris (L.) Engl. & & 10 & $\mathrm{LC}^{1}$ & Tree \\
\hline Sonneratia ovata Back. & & 11 & $\mathrm{NT}^{1}$ & Tree \\
\hline Camptostemon philippinensis (S.Vidal) Becc. & Malvaceae & 4 & $\mathrm{EN}^{1,4}$ & Tree \\
\hline Heritiera littoralis Aiton & & 6 & $\mathrm{LC}^{1}$ & Tree \\
\hline Xylocarpus granatum Koen. & Meliaceae & 15 & $\mathrm{LC}^{1}$ & Tree \\
\hline Xylocarpus moluccensis (Lam) M. Roem. & & 13 & $\mathrm{LC}^{1}$ & Tree \\
\hline Aegiceras corniculatum (L.) Blanco & Myrsinaceae & 9 & $\mathrm{LC}^{1}$ & Tree \\
\hline Aegiceras floridum Roem. \& Schult. & & 18 & $\mathrm{NT}^{1}$ & Tree \\
\hline Osbornia octodonta F. Muell. & Myrtaceae & 12 & $\mathrm{LC}^{1}$ & Tree \\
\hline Acrostichum aureum $\mathrm{L}$. & Pteridaceae & 6 & $\mathrm{LC}^{1}$ & Fern \\
\hline Acrostichum speciosumWilld. & & 15 & $\mathrm{LC}^{1}$ & Fern \\
\hline Bruguiera cylindrica $(\mathrm{L}$.$) Blume$ & Rhizophoraceae & 21 & $\mathrm{LC}^{1}$ & Tree \\
\hline Bruguiera gymnorhiza (L.) Lam. & & 8 & $\mathrm{LC}^{1}$ & Tree \\
\hline Bruguiera sexangula (Lour.) Poir. & & 13 & $\mathrm{LC}^{1}$ & Tree \\
\hline Ceriops decandra (Griff.) W.Theob. & & 7 & $\mathrm{NT}^{1}$ & Tree \\
\hline Ceriops tagal (Perr.) C.B.Rob. & & 18 & $\mathrm{LC}^{1}$ & Tree \\
\hline Rhizophora apiculata Blume & & 59 & $\mathrm{LC}^{1}$ & Tree \\
\hline Rhizophora mucronata Lam. & & 40 & $\mathrm{LC}^{1}$ & Tree \\
\hline Rhizophora stylosa Griff. & & 18 & $\mathrm{LC}^{1}$ & Tree \\
\hline Scyphiphora hydrophyllacea C.F.Gaertn. & Rubiaceae & 33 & $\mathrm{LC}^{1}$ & Tree \\
\hline \multicolumn{5}{|l|}{ Mangrove associates } \\
\hline Dolichandrone spathacea (1.f.) K.Schum. & Bignoniaceae & 8 & $\mathrm{LC}^{1}$ & Tree \\
\hline \multirow{2}{*}{ Terminalia catappa L. } & Combretaceae & 1 & $\mathrm{LC}^{3}$ & Tree \\
\hline & Total & 650 & & \\
\hline
\end{tabular}

Note: Conservation Status: LC: least concern; NT: near threatened; VU: vulnerable; EN: endangered. ${ }^{1}$ : IUCN Red List of Threatened Species 2010-2; ${ }^{2}$ : IUCN Red List of Threatened Species 2011-2; ${ }^{3}$ : IUCN Red List of Threatened Species 2019-3; 4: DAO No. $2017-11$. 
Table 2. Diversity analyses for sampled mangrove forests in Banaybanay, Davao Oriental, Philippines

\begin{tabular}{ll}
\hline Diversity indices & Value \\
\hline Species Richness & 33 \\
Shannon-Weiner Index of Diversity (H') & 3.1453 \\
$\mathrm{H}_{\max }$ & 3.4965 \\
Effective Number of Species (ENS) & 23.228 \\
Pielou's Index of Evenness (J) & 0.8995 \\
Species Index of Dominance (C) & 0.0565 \\
Simpson's Index of Diversity (D) & 0.9434 \\
\hline
\end{tabular}

\section{Habitat assessment}

Results of this study revealed that the mangrove forests in Banaybanay is comprised of trees with mean DBH ranging between 10.7 and $30.5 \mathrm{~cm}$, mean tree height between 2.88 to $16.5 \mathrm{~m}$, basal area 0.01 to $3.25 \mathrm{~m}^{-2} \mathrm{ha}^{-1}$, and stem density between 1.2 and 26.4 stems per ha (Figure 3 ).
Among the mangrove trees, $S$. alba and $S$. ovata showed the greatest mean DBH reaching to $30 \mathrm{~cm}$-wide trunks. $S$. alba comprise the largest basal area of $3.25 \mathrm{~m}^{-2} \mathrm{ha}^{-1}$ which is about $35 \%$ of the total stand basal area with stem density of 26 trees per ha. For tree height, the tallest was $S$. ovata reaching an average height of $16 \mathrm{~m}$ and then followed by $S$. caseolaris, S. alba, and B. cylindrica at around $11 \mathrm{~m}$ tall.

On the other hand, more than half $(55.23 \%)$ of the sampled mangrove stand is dominated by plants with $\mathrm{DBH}$ ranging from 11 to $20 \mathrm{~cm}$, while $19.38 \%$ are old-growth trees with larger DBH of 21 to $40 \mathrm{~cm}$ and $3 \%$ of mangroves have very wide DBH $>41 \mathrm{~cm}$. (Figure 4). The classification was based on Lillo et al. (2018) with modifications. These trees with large diameters were found in riverine areas. Most of them thrive along with the Piso and Kalubihan river system. In these barangays, towering and undisturbed trees of mangrove species are present. Transect 7 situated in Barangay Mogbongcogon has larger trees with girth ranging 31 to $40 \mathrm{~cm}$.

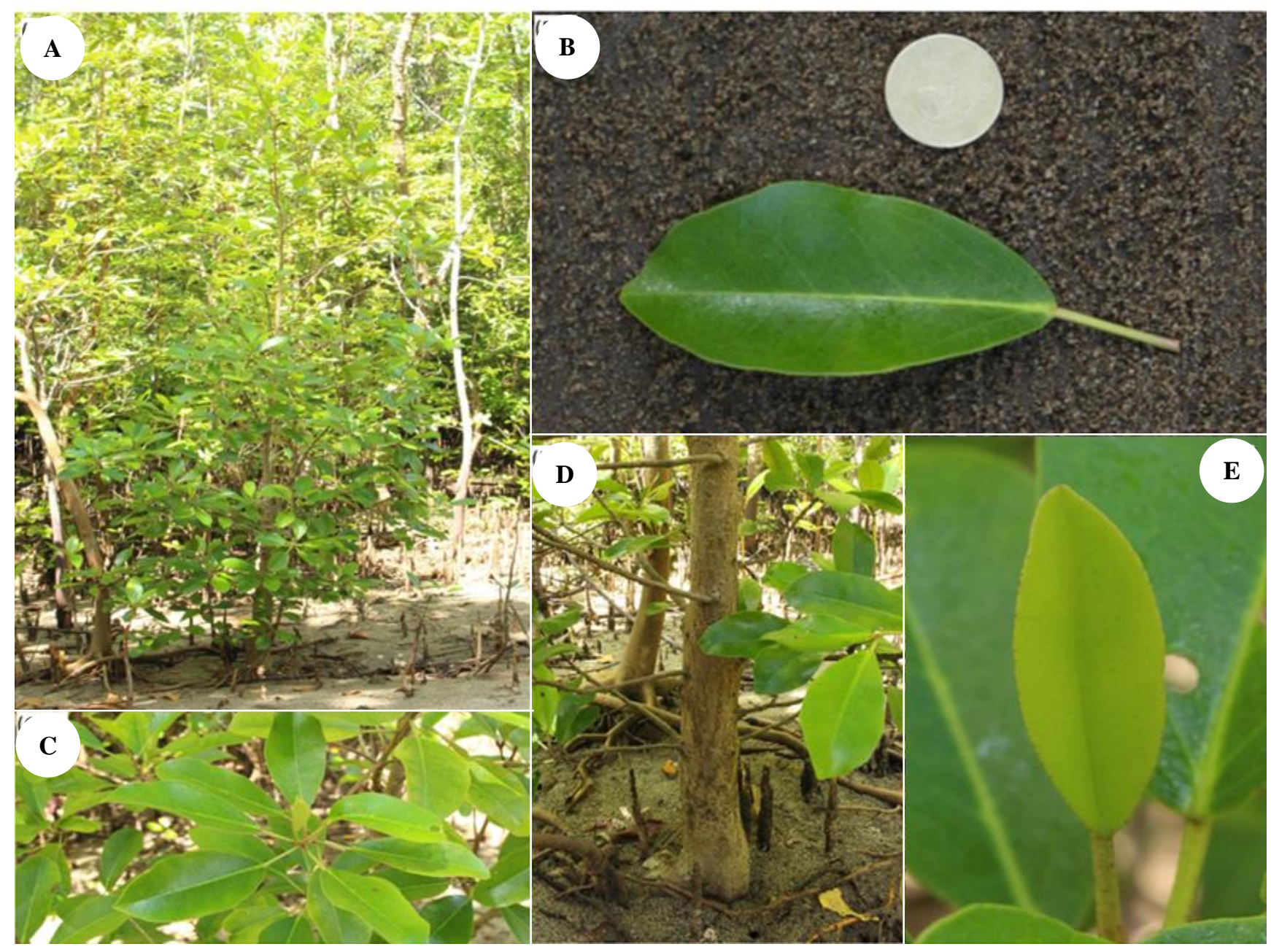

Figure 2. Camptostemon philippinensis or 'gapas-gapas' showing: A. Plant habit; B. Leaf morphology; C. Leaf formation and arrangement; D. Stem; and, E. Apical shoot observed in Banaybanay, Davao Oriental, Philippines 


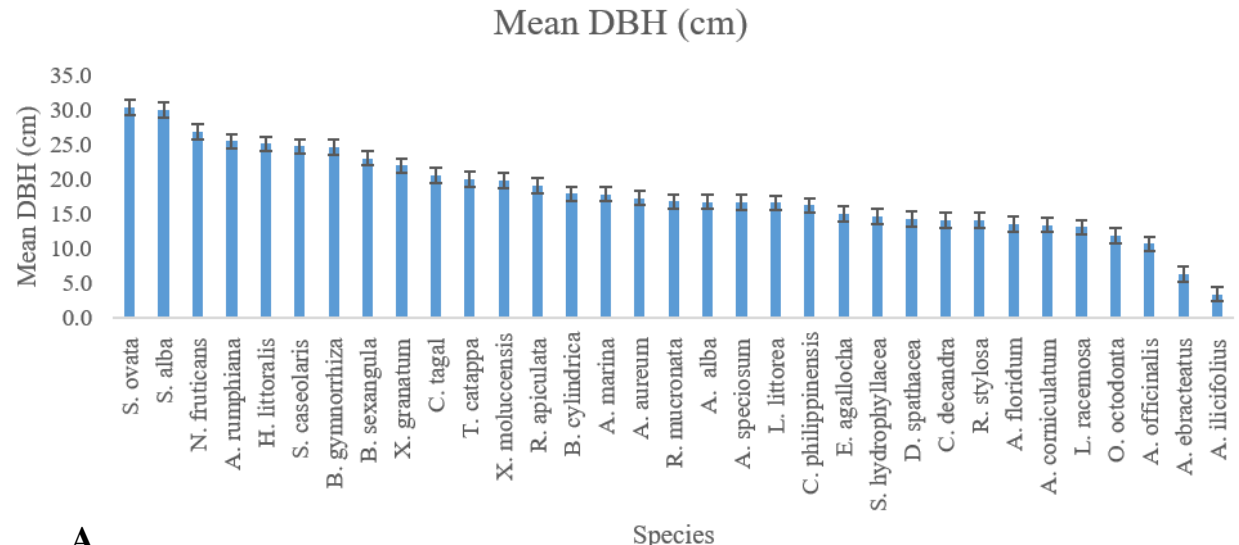

A

Mean Height (m)

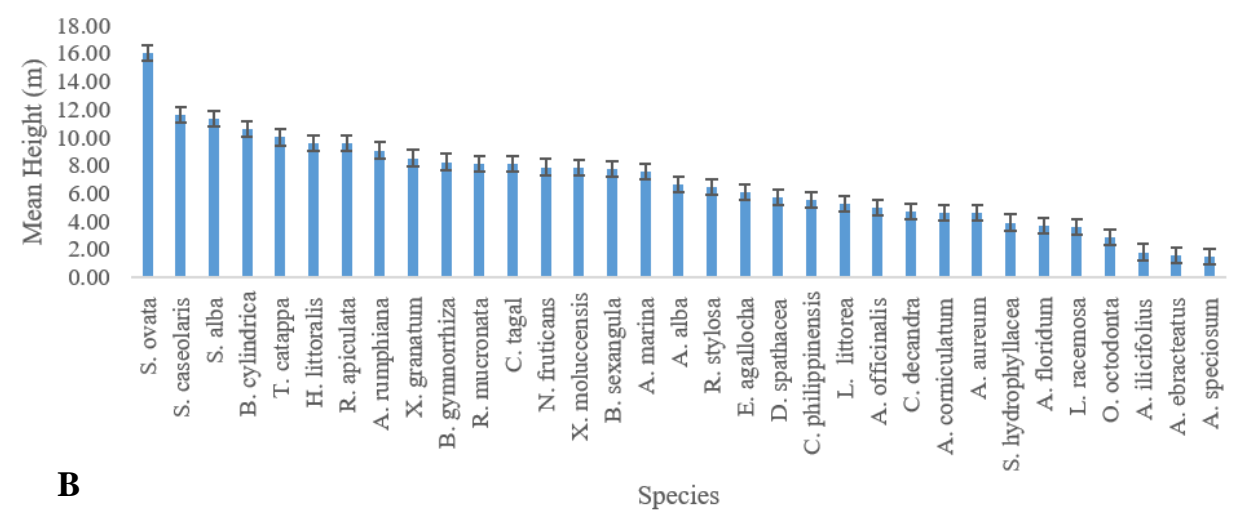

Basal Area (sq.m.)

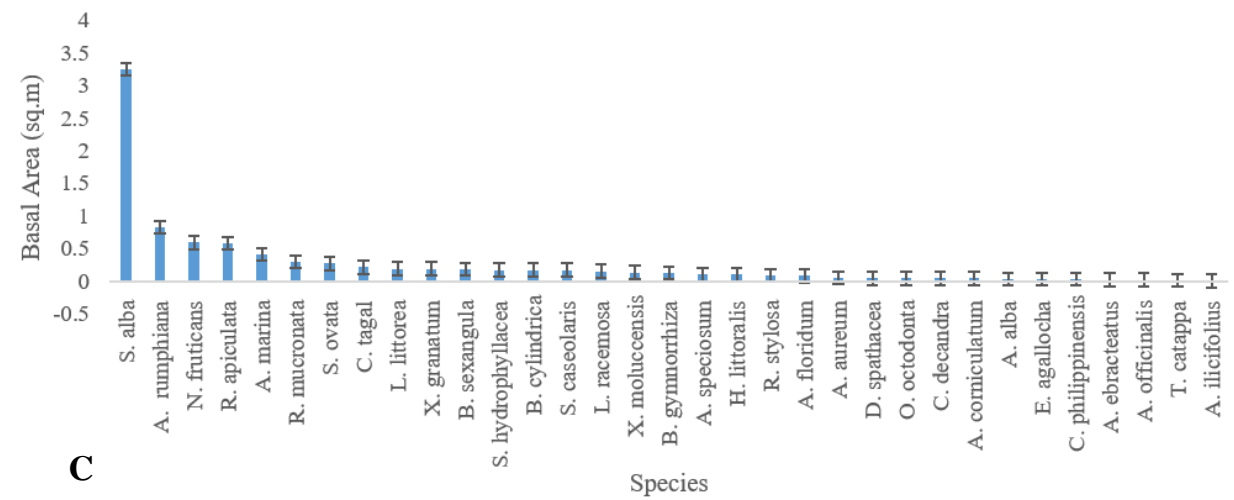

Stem Density (n/ha)

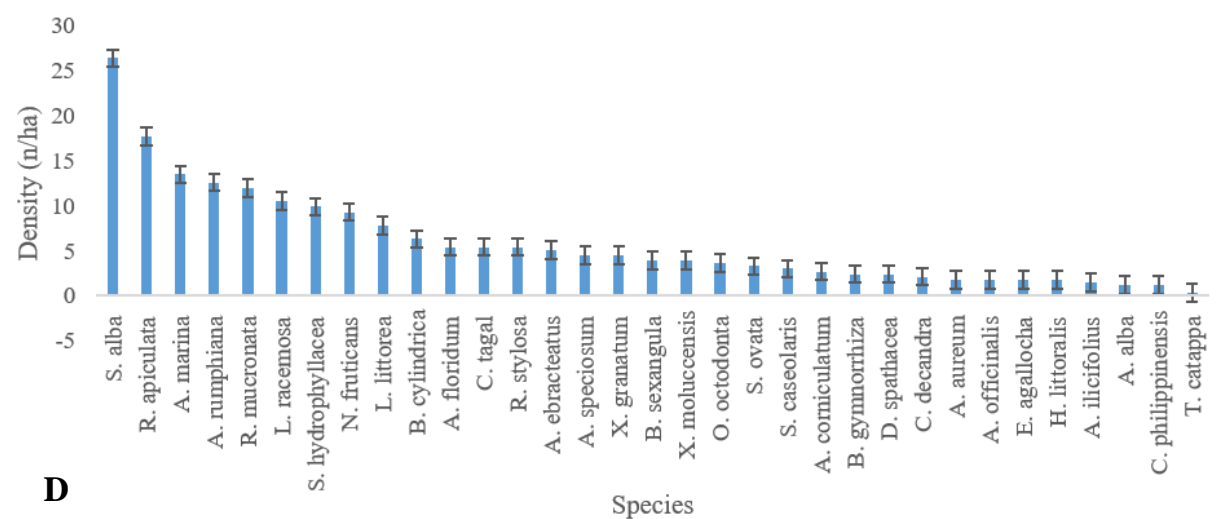

Figure 3. Habitat assessment of sampled mangrove forests in Banaybanay, Davao Oriental, Philippines showing the rankings of species in terms of: A. Mean diameter at breast height (DBH), B. Mean height, C. Basal area, and D. Stem density 


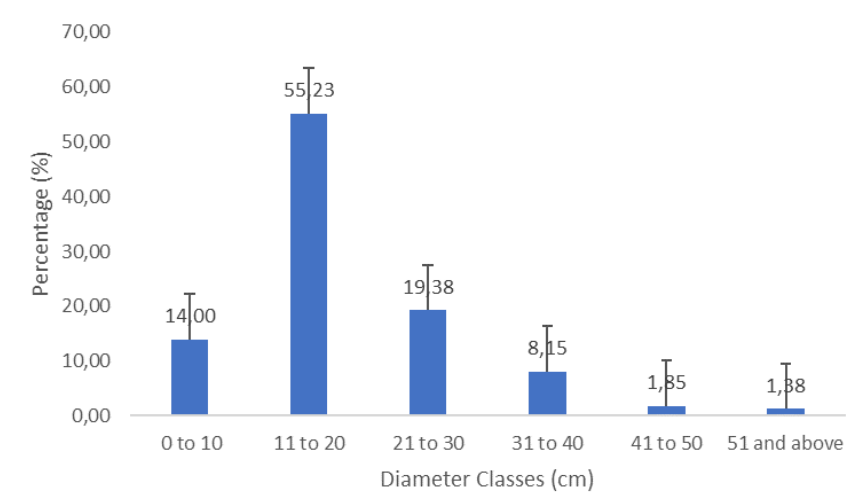

Figure 4. Diameter distribution of mangrove species recorded in Banaybanay, Davao Oriental, Philippines

Mangroves in riverine types are most productive due to freshwater influence (Perera et al. 2013). It was also observed that the locals in the area which are mostly members of the fisherfolks organization were trained by government agencies for mangrove conservation. The area is also situated near the municipal bird sanctuary which means authorities conducts regular monitoring which lessens illegal activities in both habitats. In barangay Maputi with narrow fringing mangrove, houses are directly constructed within the mangrove forest with boats and canoes attached to mangrove trees to protect them during rough weathers. While overwash type of mangrove in barangays Pintatagan and Puntalinao, fishermen hang their fishing nets underneath the trees during high tide.

\section{Vegetation analysis}

Table 3 showed the ranks of all the mangrove species of the sampled areas in Banaybanay based on importance value which considers three parameters: relative density, relative frequency, and relative dominance. Among the 33 species, Sonneratia alba or 'pagatpat' has the highest importance value $59.8 \%$, relative density $13.5 \%$, seen in most of the sampling transect lines as well as high in dominance $37.5 \%$. These imply that $S$. alba has the largest contribution to mangrove biomass in the municipality. Brown and Kleine (2012) reported that $S$. alba is a rapidly flowering and fruiting species. Much earlier, Tomlinson (1986) reported that this species possesses a physiological mechanism that controls salt, making it a more adaptive species within the mangrove community. In the mangrove forest in Banaybanay, a gigantic $S$. alba tree towers from the ground with $28.2 \mathrm{~m}$ height as the tallest tree, showing how acclimated it is in its environment.

Subsequently, $R$. apiculata $(\mathrm{IV}=24.12 \%)$, A. rumphiana (IV=22.71\%), and A. marina $(\mathrm{IV}=18.02 \%)$ are next in rank to $S$. alba. The species of Rhizophora found in the municipality are utilized for tannin extraction locally known as "tungog" production. 'Tungog' is a material extracted from the bark of Rhizophora species which provides the coloring agent for the coconut wine locally known as "tuba". Improper debarking of trees can later harm growth and survival of the species leading to loss of individual population (FAO 1994; Bandaranayake 1998).

Sonneratia spp. and Rhizophora spp. being popular to locals are spared from cutting by the locals. Also, most of the mangrove tree planting activities conducted in the area use the seedlings of these species giving them financial benefits in the process. Apparently, this promotes the abundance of the species in the area.

Five more species ranked after A. marina which belongs to top ten species have importance values that ranged between 10 and $16 \%$. These are $N$. fruticans, $R$. mucronata, L. racemosa, S. hydrophyllacea, and L. littorea. All other species have importance value of less than $10 \%$ comprised of other true mangrove trees, ferns, palm, and associate species. Under true mangroves, $C$. philippinensis was ranked as the lowest with mean DBH of $16.25 \mathrm{~cm}$ reaching around $6 \mathrm{~m}$ tall. With very few individuals, this species occupied only a small basal area of 0.03 and very low stem density of 0.82 per hectare.

In conclusion, rapid mangrove assessment in six barangays of Banaybanay, Davao Oriental northeast of Davao Gulf showed high species diversity. A total of 33 mangrove species representing 14 families with 30 true mangroves and 2 associates were recorded in different forest types: riverine, overwash and fringing. ShannonWeiner diversity showed a high value $(\mathrm{H}=3.145)$, with high evenness $(\mathrm{J}=0.89)$ and low dominance $(\mathrm{C}=0.05)$. In terms of community structural features, $S$. alba has the greatest importance value around $60 \%$ due to its high relative density, relative frequency, and relative dominance. S. alba has also the highest mean dbh and means height suggesting its largest contribution to biomass on the mangrove community. Rhizophoraceae is the most represented with eight different species. Apparently, these species are the most popular to locals and are promoted for mangrove planting subsequently influencing the abundance of the species. Meanwhile, the indigenous and endangered species, C. philippinensis was ranked the lowest under true mangroves with very low basal area, stem density, and importance value that calls for immediate protection. Conservation efforts should be exerted for vulnerable $A$. rumphiana, and near-threatened species such as $A$. floridum, A. rumphiana, C. decandra, and S. ovata. Hence, we recommend immediate protection and conservation measures of the mangrove forests in Banaybanay due to increasing anthropogenic activities and environmental problems observed in the area. An Information Education Campaign (IEC) should be considered to raise awareness in the communities residing near their mangrove forest. 
Table 3. Community structural analysis of mangrove species found in Banaybanay, Davao Oriental, Philippines

\begin{tabular}{|c|c|c|c|c|c|}
\hline Rank & Species & $\begin{array}{c}\text { Relative ensity } \\
(\%)\end{array}$ & $\begin{array}{c}\text { Relative frequency } \\
(\%)\end{array}$ & $\begin{array}{c}\text { Relative dominance } \\
(\%)\end{array}$ & $\begin{array}{c}\text { Importance } \\
\text { value }(\%)\end{array}$ \\
\hline 1 & Sonneratia alba & 13.54 & 8.70 & 37.56 & 59.79 \\
\hline 2 & Rhizophora apiculata & 9.08 & 8.30 & 6.74 & 24.12 \\
\hline 3 & Avicennia rumphiana & 6.46 & 6.72 & 9.53 & 22.71 \\
\hline 4 & Avicennia marina & 6.92 & 6.32 & 4.78 & 18.02 \\
\hline 5 & Nypa fruticans & 4.77 & 4.74 & 6.78 & 16.29 \\
\hline 6 & Rhizophora mucronata & 6.15 & 6.32 & 3.38 & 15.86 \\
\hline 7 & Lumnitzera racemosa & 5.38 & 5.53 & 1.75 & 12.67 \\
\hline 8 & Scyphiphora hydrophyllacea & 5.08 & 5.14 & 2.01 & 12.22 \\
\hline 9 & Lumnitzera littorea & 4.00 & 3.95 & 2.23 & 10.18 \\
\hline 10 & Ceriops tagal & 2.77 & 3.16 & 2.48 & 8.41 \\
\hline 11 & Xylocarpus granatum & 2.31 & 3.56 & 2.25 & 8.12 \\
\hline 12 & Bruguiera cylindrica & 3.23 & 2.77 & 2.00 & 7.99 \\
\hline 13 & Rhizophora stylosa & 2.77 & 3.56 & 1.02 & 7.35 \\
\hline 14 & Aegiceras floridum & 2.77 & 3.16 & 0.93 & 6.86 \\
\hline 15 & Sonneratia ovata & 1.69 & 1.98 & 3.16 & 6.83 \\
\hline 16 & Acrostichum speciosum & 2.31 & 2.77 & 1.21 & 6.29 \\
\hline 17 & Bruguiera sexangula & 2.00 & 1.98 & 2.08 & 6.05 \\
\hline 18 & Acanthus ebracteatus & 2.62 & 3.16 & 0.27 & 6.05 \\
\hline 19 & Xylocarpus moluccensis & 2.00 & 2.37 & 1.55 & 5.92 \\
\hline 20 & Sonneratia caseolaris & 1.54 & 1.19 & 1.99 & 4.72 \\
\hline 21 & Bruguiera gymnorrhiza & 1.23 & 1.19 & 1.42 & 3.83 \\
\hline 22 & Dolichandrone spathacea & 1.23 & 1.98 & 0.46 & 3.67 \\
\hline 23 & Osbornia octodonta & 1.85 & 1.19 & 0.48 & 3.51 \\
\hline 24 & Heritiera littoralis & 0.92 & 1.19 & 1.19 & 3.29 \\
\hline 25 & Ceriops decandra & 1.08 & 1.58 & 0.41 & 3.07 \\
\hline 26 & Aegiceras corniculatum & 1.38 & 1.19 & 0.47 & 3.04 \\
\hline 27 & Acrostichum aureum & 0.92 & 1.19 & 0.54 & 2.65 \\
\hline 28 & Avicennia officinalis & 0.92 & 1.19 & 0.19 & 2.30 \\
\hline 29 & Avicennia alba & 0.62 & 1.19 & 0.37 & 2.17 \\
\hline 30 & Excoecaria agallocha & 0.92 & 0.79 & 0.37 & 2.09 \\
\hline 31 & Acanthus ilicifolius & 0.77 & 1.19 & 0.02 & 1.97 \\
\hline 32 & Camptostemon philippinensis & 0.62 & 0.40 & 0.29 & 1.30 \\
\hline \multirow[t]{2}{*}{33} & Terminalia catappa & 0.15 & 0.40 & 0.11 & 0.66 \\
\hline & Total & 100.00 & 100.00 & 100.00 & 300.0 \\
\hline
\end{tabular}

\section{ACKNOWLEDGEMENTS}

This study was funded by the Republic of the Philippines, Commission on Higher Education DiscoveryApplied Research and Extension for Trans/Interdisciplinary Opportunities (CHED DARE-TO) Research Grant 2018-2020 under the project titled "Vulnerability Assessment of Coastal Areas in Davao Gulf to Climate Related Hazards" implemented by the University of the Philippines Mindanao and Davao Del Norte State College. We are grateful for the support of the local government of Banaybanay headed by Mayor Adalia L.Tambuang through the Office of Municipal Agriculture led by Ms. Ester M. Solamo. Assistance rendered by field technicians during field sampling is highly appreciated.

\section{REFERENCES}

Alcala AC, Ingles, JA, Bucol AA 2008. Review of the biodiversity of Southern Philippine Seas. Philipp Scient 45: 1-61.
Bagarinao TU, Primavera JH. 2005. Code of practice for sustainable use of mangrove ecosystems for aquaculture in Southeast Asia. SEAFDEC Aquaculture Department Tigbauan, Iloilo, Philippines.

Baleta FN, Casalamitao Jr RS. 2016. Species composition, diversity and abundance of mangroves along the estuarine area of Maligaya, Palanan, Isabela, Philippines. Intl J Fish Aquat 4 (2): 303-307.

Baliton RS, Landicho LD, Cabahug RED, Paelmo RF, Laruan KA, Rodriguez RS, Visco RG, Castillo AKA. 2020. Ecological services of agroforestry systems in selected upland farming communities in the Philippines. Biodiversitas. 21 (2): 707-717. DOI: 10.13057/biodiv/d210237

Bandaranayake WM. 1998. Traditional and medicinal uses of mangroves. Mangr Salt Marsh 2: 133-148.

Bignoli JD. 2011. Acanthus ilicifolius. The IUCN Red List of Threatened Species 2011: e.T168780A6536949. DOI: 10.2305/IUCN.UK.20111.RLTS.T168780A6536949.en

Brown S, Kleine D. 2012. Biosphere reserve mangroves Kien Giang biosphere reserve. Deutsche Gesellschaft für Internationale Zusammenarbeit (GIZ), Germany.

Buitre M, Zhang H, Lin H. 2019. The mangrove forests change and impacts from tropical cyclones in the Philippines using time-series satellite imagery. Remote Sens 11 (6): 688.

Bunting P, Rosenqvist A, Lucas RM, Rebelo L, Hilarides L, Thomas N, Hardy A, Itoh T, Shimada M, Finlayson CM. 2018. The global mangrove watch - a new 2010 global baseline of mangrove extent. Remote Sens 10 (10): 1669 
Cabrera JS, Lee HS. 2018. Impacts of climate change on flood-prone areas in Davao Oriental, Philippines. Water 10: 893. DOI: 10.3390/w10070893

Calicdan MA, Rebancos C, Ancog R, Baginon N. 2015. Assessment of mangrove flora of Palaui Island Protected Landscape and Seascapes (PIPLS) San Vicente, Sta. Ana, Cagayan Valley, Philippines. Asian J Conserv Biol 4 (1): 15-19.

Cañizares L, Seronay R. 2016. Diversity and species composition of mangroves in Barangay Imelda, Dinagat Island, Philippines. AACL Bioflux 9 (3): 518-26.

Cardillo J, Novero AU. 2018. Assessment of mangrove diversity in Santa Cruz, Davao del Sur, Philippines. J Bio Env Sci 14 (2): 53-62.

Conservation International Philippines, Department of Environment and Natural Resources-Protected Areas and Wildlife Bureau, Department of Agriculture-Bureau of Fisheries and Aquatic Resources. 2009. Priority Sites for Conservation in the Philippines: Marine and Terrestrial Key Biodiversity Areas Map. Conservation International Philippines, Manila.

Dangan-Galon F, Dolorosa RG, Sespeñe JS, Mendoza NI. 2016. Diversity and structural complexity of mangrove forest along Puerto Princesa Bay, Palawan Island, Philippines. J Mar Isl Cult 5 (2): 118-125.

Department of Environment and Natural Resources Administrative Order (DAO) NO. 2007-01. 2007. Establishing the national list of threatened Philippine plants and their categories, and the list of other wildlife species. Department of Environment and Natural Resources. Diliman, Quezon City.

Department of Environment and Natural Resources Administrative Order (DAO) NO. 2017-11. 2017. Updated national list of threatened Philippine plants and their Categories. Department of Environment and Natural Resources. Diliman, Quezon City.

Dieta RE, Dieta FC. 2015. The Philippine National Aquasilviculture Program. In: Romana-Eguia MRR, F. D. Parado-Estepa, N. D Salayo, \& M. J. H. Lebata-Ramos (eds.), Resource enhancement and sustainable aquaculture practices in Southeast Asia: challenges in responsible production of aquatic species: Proceedings of the International Workshop on Resource Enhancement and Sustainable Aquaculture (RESA) Practices in Southeast Asia 2014. Tigbauan, Iloilo, Philippines: Aquaculture Dept., Southeast Asian Fisheries Development Center.

Duke N, Kathiresan K, Salmo III SG, Fernando ES, Peras JR, Sukardjo S Miyagi T. 2010. Avicennia alba, Avicennia officinalis, Avicennia rumphiana, Bruguiera cylindrica, Bruguiera gymnorhiza, Bruguiera sexangula, Ceriops decandra, Ceriops tagal, Dolichandrone spathacea, Heritiera littoralis, Rhizophor apiculata, Rhizophora mucronata, Rhizophora stylosa. The IUCN Red List of Threatened Species 2010-2. Retrieved from https://www.iucnredlist.org/.

Duke N, Kathiresan K, Salmo III SG, Fernando ES, Peras JR, Sukardjo S, MiyagI T, Ellison J, Koedam NE, Wang Y, Primavera J, Jin Eong O, Wan-Hong Yong J, Ngoc Nam V. 2010. Avicennia marina. The IUCN Red List of Threatened Species 2010: e.T178828A7619457. DOI: 10.2305/IUCN.UK.2010-2.RLTS.T178828A7619457.en.

Ellison J, Koedam NE, Wang Y, Primavera J, Jin Eong O, Wan-Hong Yong J., Ngoc Nam V. 2010. Acanthus ebracteatus, Acrostichum aureum, Acrostichum speciosum, Aegiceras corniculatum, Aegiceras floridum, Excoecaria agallocha, Lumnitzera littorea, Nypa fruticans, Osbornia octodanta, Scyphiphora hydrophyllacea, Xylocarpus granatum, Xylocarpus moluccensis. The IUCN Red List of Threatened Species 2010-2. Retrieved from https://www.iucnredlist.org/.

Fernando ES 1998. Forest formations and flora of the Philippines: Handout in FBS 21. UPLB, Philippines. In: Baliton RS, Landicho LD, Cabahug RED, Paelmo RF, Laruan KA, Rodriguez RS, Visco RG, Castillo AKA. 2020. Ecological services of agroforestry systems in selected upland farming communities in the Philippines. Biodiversitas. 21 (2): 707-717. DOI: 10.13057/biodiv/d210237.

Kathiresan K, Salmo III SG, Fernando ES, Peras JR, Sukardjo S, Miyagi T, Ellison J, Koedam NE, Wang Y, Primavera J, Jin Eong O, WanHong Yong J, Ngoc Nam V. 2010. Sonneratia alba, Sonneratia caseolaris, Sonenratia ovata, The IUCN Red List of Threatened Species 2010-2. Retrieved from https://www.iucnredlist.org/.

English S, Wilkinson C, Baker V. 1994. Survey manual for tropical marine resources, $2^{\text {nd }}$ ed. The Australian Institute of Marine Science, Townville, Australia.

Farley J, Batker D, De La Torre I, Hudspeth T. 2010. Conserving mangrove ecosystems in the Philippines: transcending disciplinary and institutional borders. Environ Manag 45 (1): 39-51.
Faustino AZ, Madela H, Castor R, Muroda A, Chavez MN. 2020. Community mapping and vegetational analysis of the mangrove forest in Calabanga, San Miguel Bay, Philippines. E3S Web of Conferences 147 (2): 02017

Fernando ES, Pancho JV. 1980. Mangrove trees of the Philippines. Sylvatrop Philipp For Res J 5 (1): 35-54.

Food Agriculture Organization (FAO). 1994. Mangrove forest management guidelines. FAO Forestry Department, Rome, Italy.

Food Agriculture Organization (FAO). 2010. Global Forest Resources Assessment 2010. FAO, Rome, Italy.

Forest Management Bureau (FMB). 2010. Philippine forestry statistics. Forest Management Bureau, Philippines. Retrieved from http://forestry.denr.gov.ph/index.php/statistics/philippines-forestrystatistics on 29 October 2020 .

Garcia KB, Malabrigo PL, Gevaña DT. 2014. Philippines' mangrove ecosystem: status, threats, and conservation. In: Ibrahim F-, Latiff A, Hakeem KR, Ozturk M (eds.). Mangrove Ecosystems of Asia: Status, Challenges, and Management Strategies. Springer Science+Business Media, New York.

Giesen W, Wulffraat S, Zieren M, Scholten L. 2007. Mangrove Guidebook for Southeast Asia. FAO Regional Office for Asia and the Pacific, Bangkok, Thailand.

International Union for the Conservation of Nature (IUCN). 2020. The IUCN Red List of Threatened Species 2010-2; 2011-1; 2019-3. Retrieved from https://www.iucnredlist.org/. on 24 October 2020.

Lillo EP, Fernando ES, Lillo MJR. 2018. Plant diversity and structure of forest habitat types on Dinagat Island, Philippines. J Asia Pac Biodivers. DOI: 10.1016/j.japb.2018.07.003.

Long JB, Giri C. 2011. Mapping the Philippines' mangrove forest using landsat imagery. Sensors 11:2972-2981.

Novero AU, Pasaporte MS, Aurelio Jr RM, Madanguit CJG, Tinoy MRM, Luayon MS, Oñez JPL, Daquiado EGB, Diez JMA, Ordaneza JE, Riños LJ, Capin NC, Pototan BL, Tan HG, Polinar MDO, Nebres DI, Nanola Jr CL. 2019. The use of light detection and ranging (LiDAR) technology and GIS in the assessment and mapping of bioresources in Davao region, Mindanao Island, Philippines. Rem Sens Appl Soc Environ 13: 1-11.

Nugroho TS, Fahrudin A, Yulianda F, Bengen DG. 2019. Structure and composition of riverine and fringe mangroves at Muara Kubu protected areas, West Kalimantan, Indonesia. AACL Bioflux 12 (1): 378-393.

Pelser PB, Barcelona JF, Nickrent DL. (eds.). 2011 onwards. Co's digital flora of the Philippines. Retrieved from www.philippineplants.org.

Perera KARS, Amarasinghe MD, Somaratna S. 2013. Vegetation structure and species distribution of mangroves along a soil salinity gradient in a micro tidal estuary on the north-western coast of Sri Lanka. Amer J Mar Sci 1 (2013): 7-15. DOI: 10.12691/marine-1-1-2.

Philippine Institute for Development Studies (PIDS). 2005. Basics on Philippine climatology. Philippine Institute for Development Studies. $2: 2$

Picardal JP, Avila SR, Tano MF, Marababol MS. 2011. The species composition and associated fauna of the mangrove forest in Tabuk and Cabgan Islets, Palompon, Leyte, Philippines. CNU J Higher Educat 5 (1): 1-18.

Pototan BL, Capin NC, Tinoy MRM, Novero AU. 2017. Diversity of mangrove species in three municipalities of Davao Del Norte, Philippines. AACL Bioflux 10 (6): 1569-1580.

Primavera JH. 1995. Mangroves and Brackish Water Pond Culture in the Philippines. Hydrobiologia 295: 303-309.

Primavera JH, Sadaba RS, Lebara M, Altamirano JP. 2004. Handbook of mangroves in the Philippines-Panay. SEAFDEC Aquaculture Department. lloilo, Philippines.

Primavera J.H. 2009. Field guide to Philippine mangroves. Makati, Philippines.

Primavera JH, Sadaba RS. 2012. Beach forest species and mangrove associtaes in the Philippines. SEAFDEC Aquaculture Department. Iloilo, Philippines.

Primavera JH, Yap WG, Savaris JP, Loma RJA, Moscoso ADE, Coching JD, Montilijao, Poingan RP, Tayo ID. 2014. Manual on mangrove reversion of abandoned and illegal brackishwater fishponds. Mangrove Manual Series No. 2, $1^{\text {st }}$ ed. Zoological Society of London - CMRP Philippines, Inc.

Spalding MD, Blasco F, Field C. 1997. World mangrove atlas. The International Society for Mangrove Ecosystems, WCMC, National Council for Scientific Research, Paris 
Thomson L, Evans B. 2019. Terminalia catappa. The IUCN Red List of Threatened Species 2019: e.T61989853A61989855. Retrieved from DOI: 10.2305/IUCN.UK.2019-3.RLTS.T61989853A61989855.en.

Tomlinson P. 1986. The Botany of Mangroves. Cambridge Tropical Biology Series, London.

Van Lavieren H, Spalding M, Alongi DM, Kainuma M, Clusener-Godt M, Adeel Z. 2012. Policy Brief. Securing the future of mangroves. United Nations University, Canada.
Vie JC, Hilton-Taylor C, Pollok C, Ragle J, Stuart J, Stuart SN, Tong R. 2008. The IUCN Red List: a key conservation tool. In: Vié JC, Hilton-Taylor C, Stuart SN (eds.). The 2008 Review of The IUCN Red List of Threatened Species. IUCN Gland, Switzerland. 